\title{
On Bensonites fusiformis, sp. nov., a fossil associated with Stauropteris burntislandica, P. Bertrand, and on the sporangia of the latter.
}

BY

\begin{abstract}
RINA SCOTT, F.L.S.
With Plate XXXIV and seven Figures in the Text.
\end{abstract}

SEVERAL years ago Miss Benson noticed in her slides from Burntisland

(Lower Carboniferous), curious spindle-shaped objects, tapering at one end and at the other terminating in a head, containing sometimes one spherical body and sometimes a double, hourglass-shaped body, Plate XXXIV, fig. 6 .

Since then they have been frequently observed, especially in material rich in Stauropteris burntislandica, P. Bert. They have been provisionally named Bensonites fusiformis by Dr. Scott.

Text-figs. I, 2, and 3 are photographs of Bensonites cut in a longitudinal direction. Just recently it has been discovered that the Bensonites is borne on a pedicel. Text-fig. I, $p$.

We have not been able to find a clear case of attachment of the pedicel to a Stauropteris burntislandica petiole, Plate XXXIV, fig. 4, but they are very probably borne in pairs on the lateral pedicels shown in Plate XXXIV, fig. 3. Miss Benson has slides which confirm this.

The 'body' of Bensonites appears to be composed of regular spherical cells surrounded by an epidermal layer, which is often imperfectly preserved (it is absent in Text-fig. 1). It is well seen, however, in longitudinal section in Text-fig. 2, where it completely envelops the Bensonites, and in transverse section in Text-figs. $4(a$ and $b)$ and $5(c)$. The transverse section in Text-fig. 5 is strikingly like a section of the gland of Lyginodendron oldhamium. ${ }^{1}$

From the first a strand of delicate elements has been noticed running up from the base, Text-figs. I and 3 (v.s.). Lately we have been fortunate in being able to demonstrate without any doubt that this is really a vascular strand, Plate XXXIV, fig. 5. Text-fig. 6 shows the two spiral elements indicated in Plate XXXIV, fig. 5, enlarged. Fig. 18 .

1 Oliver and Scott, on Lagenostoma Lomaxi, Phil. Trans., vol. cxvii, I904, Plate VIII, [Annals of Botany, Vo1. XXII. No. LXXXVIII. October, 1908.] 


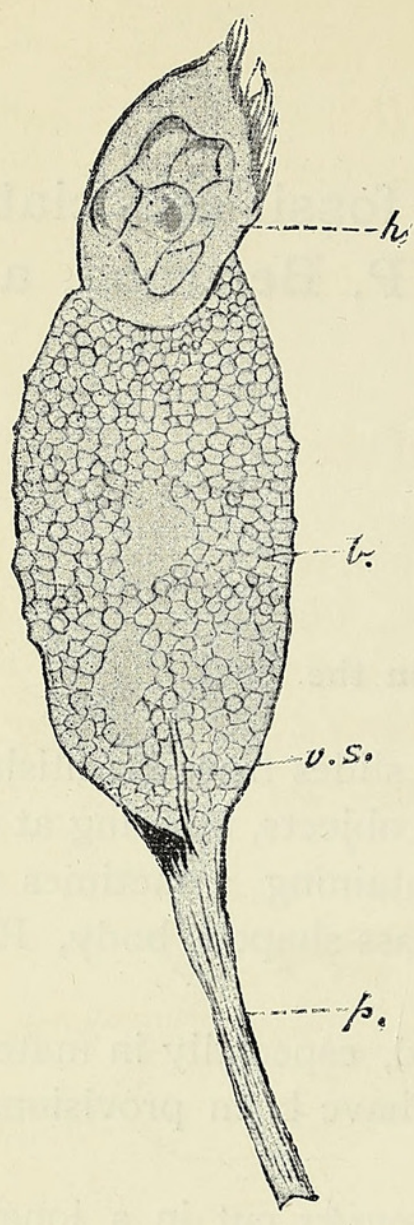

1.

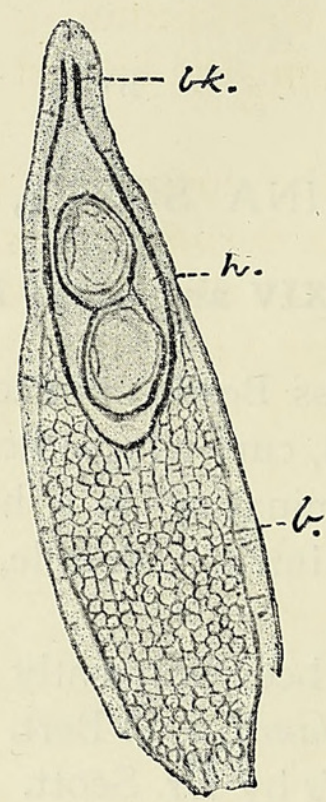

2.
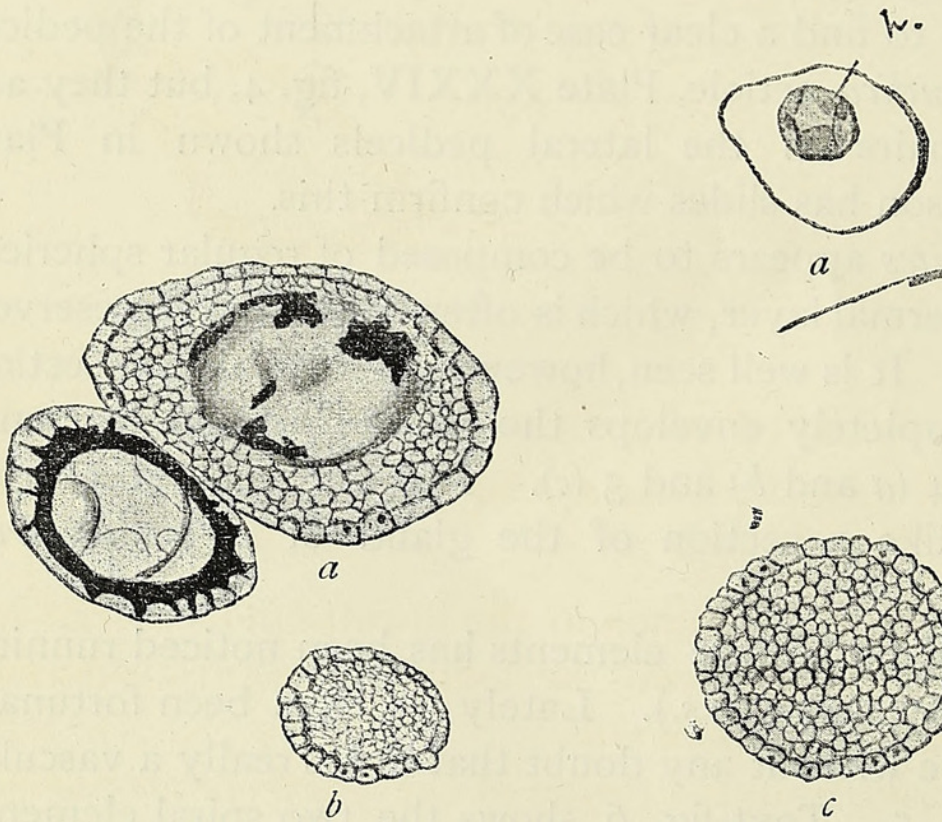

4 .

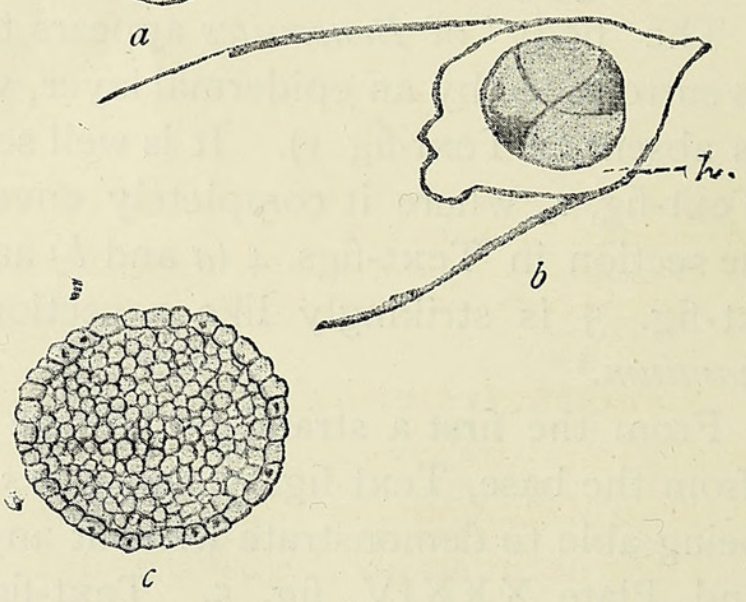

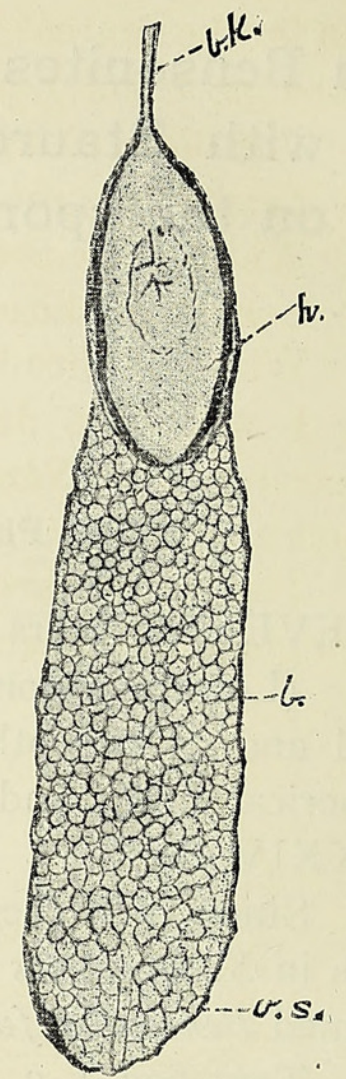

3 .

5.

Fig. I. Bensonites fusiformis, showing head $h$, body $b$, pedicel $p . \quad \times 50 . \quad$ S. Coll. 443 .

Fig. 2. Bensonites fusiformis, showing beak $b k$, head $h$, and body $b$. The epidermal layer is complete. $\times 50$. S. Coll. $3^{8} 3$.

Fig. 3. Bensonites fusiformis, showing beak $b k$, head $h$, body $b$, and vascular strand $v . s$. shown more magnified in Fig. 6 . From a slide of Miss Benson's. $\times 50$.

Fig. 4. Bensonites fusiformis, showing (a) two adjoining transverse sections, one through the lower part of the head, and one through the middle of the head. The small section (b) is through the lower end of the 'body'. S. Coll. $383 . \quad \times 50$.

Fig. 5. Bensonites fusiformis, trans. (a) and long. sections (b) through the head $h$, and (c) trans. section through the broadest part of the body. S. Coll. $3^{8} 3 . \times 50$. 
with Stauropteris burniislandica, P. Bertrand, Éc. 685

The 'head' of the Bensonites is well marked off from the 'body' and ends at the apex in a long beak: Text-figs. 2 and $3(b k)$. A very common form for the contents to assume is that of an hour-glass, Plate XXXIV, fig. 6, Text-figs. 2 and 7 , or it may be spherical in shape: Text-fig. 5 ( $a$ and $b$ ).

The dimensions of an average Bensonites are as follows:

Length, I.3 mm. ; width, $\cdot 42 \mathrm{~mm}$.

Width of pedicel from $\cdot 05-12 \mathrm{~mm}$.

Length of 'head' $60 \mathrm{~mm}$., the longest observed 'hour-glass' head.

Width of 'head' $.24 \mathrm{~mm}$.

I will now describe the sporangia, which we have recently found associated with Stauropteris burntislandica, P. Bert., Plate XXXIV, figs. $I$ and 2, and then return to the discussion of the Bensonites problem.

The sporangia of another Stauropteris - S. oldhamia, with their germinating spores-have been fully described by Dr. Scott. ${ }^{1}$

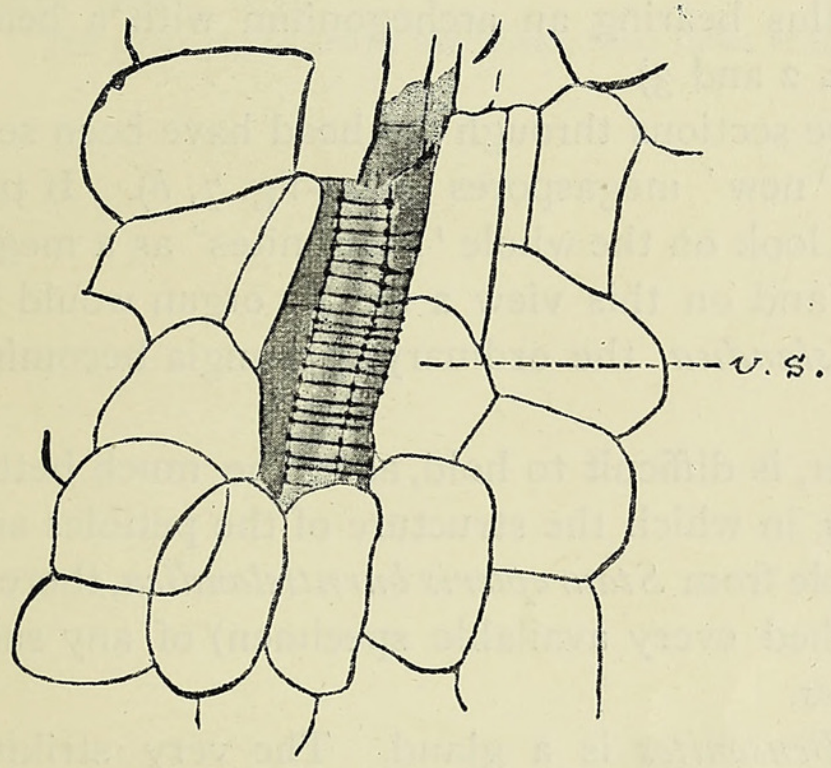

6.
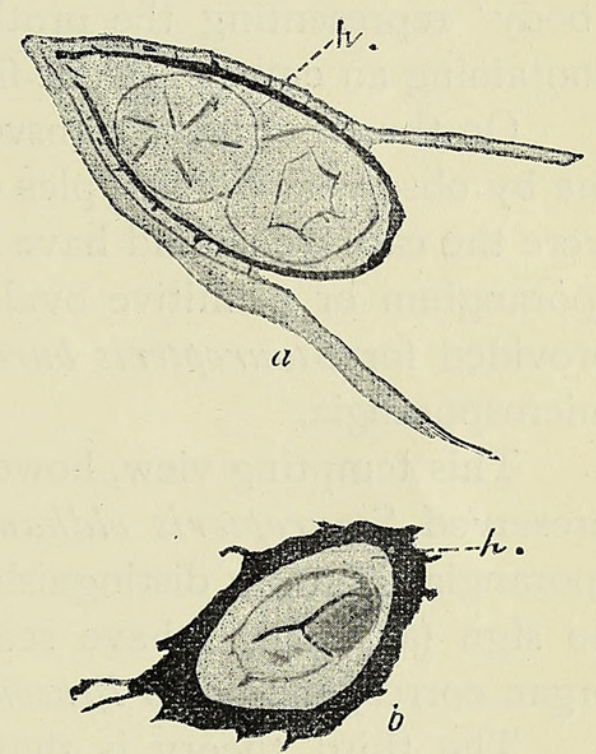

7.

Fig. 6. Bensonites fusiformis. Enlarged drawing of the vascular strand, vs., showing two spiral elements. $x$ about 400 .

Fig. 7. Bensonites fusiformis (a) longitudinal section of 'head' with hour-glass-shaped contents, and $(b)$ oblique section of another 'head'.

Stauropteris burntislandica, so common in the Burntisland material, has now disclosed its sporangia, and they will be found to be extraordinarily like those of its younger relation $S$. oldhamia.

They occur in great quantity in the region of the Stauropteris petioles, Plate XXXIV, fig. 4. A single sporangium is shown in Plate XXXIV, figs. 1 and 2.

1 D. H. Scott, Germinating spores in a fossil fern sporangium, New Phytologist, vol. iii, 1904. Sporangia of Stauropteris oldhamia, ibid., vol. iv, r905. The occurrence of germinating spores in Stauropteris oldhamia, ibid., vol. v, 1906. 
686 Scott.-On Bensonites fusiformis, sp. nov., a fossil associated

The sporangia are almost spherical in shape; the 'stomium' is well shown in Plate XXXIV, figs. I and 2, st.

They are generally filled with spores. I have been fortunate in finding one sporangium filled with germinating spores (Plate XXXIV, fig. 2) though the stages of germination are not so clearly shown as in S. oldhamia.

This is of the greater interest as it is the third example in this genus in which the spores have been found in a state of germination. It is curious that up to the present this should be the only genus of fossil plants in which this phenomenon has been observed.

We now return to a fuller consideration of the 'head' of Bensonites, and to a discussion of the various views which have been held about the fossil since it was first noticed.

The strong resemblance of the sporangial wall of Stauropteris burntislandica to the epidermis of Bensonites gave rise to the suggestion that the 'Bensonites' might be an aposporous outgrowth from a sporangium, the 'body' representing the prothallus bearing an archegonium with a beak, containing an embryo (Text-figs. 2 and 3 ).

On the other hand transverse sections through the head have been sent me by observers as examples of 'new' megaspores (Text-fig. $7, b$ ). If this were the case we should have to look on the whole 'Bensonites' as a megasporangium or primitive ovule, and on this view a female organ would be provided for Stauropteris burntislandica, the ordinary sporangia becoming microsporangia.

This tempting view, however, is difficult to hold, as in the much better preserved Stauropteris oldhamia, in which the structure of the petioles and sporangia is hardly distinguishable from Stauropteris burntislandica, there is no sign (although I have searched every available specimen) of any such organ corresponding to Bensonites.

The third theory is that Bensonites is a gland. The very striking resemblance of the tissue to that found in Lyginodendron oldhamium glands supports this view. It is known that glands of some importance occurred in one genus of Carboniferous plants, so that it is quite probable that they should be found in others too.

If this view be the right one, the glands must have been of some considerable importance; they are supplied with a vascular strand and a beak, through which their contents could have been ejected. The 'head' in this case would represent the partially disorganized tissue, in which the secretion was formed. 
with Stauropteris burntislandica, P. Bertrand, \&c. 687

\section{DESCRIPTION OF PLATE XXXIV}

Illustrating Mrs. D. H. Scott's paper on Bensoniles and Stauropteris.

Fig. I. Stauropteris burntislandica, P. Pert. Sporangium containing spores. st. $=$ stomium. $\times 5$.

Fig. 2. Stauropteris burntislandica, P. Bert. Sporangium containing germinating spores. S. Coll., $436 . \times 50$.

Fig. 3. Stauropteris burntislandica, P. Bert. Pedicels, $p, p$, probably bearing Bensonites fusiformis. $\times 50$.

Fig. 4. Stauropteris burntislandica. Trans. petiole. S. Coll. $489 . \quad \times 50$.

Fig. 5. Bensonites fusiformis. Longitudinal section through part of the base, showing vascular strand, which is shown in detail in Text-fig. $6 . \times$ about 400 .

Fig. 6. Bensonites fusiformis. Longitudinal section with portion of pedicel and hour-glassshaped 'head'. $\times 5$.

The photographs are by Mr. Tams, from slides in the Scott collection. 
Annals of Botany,
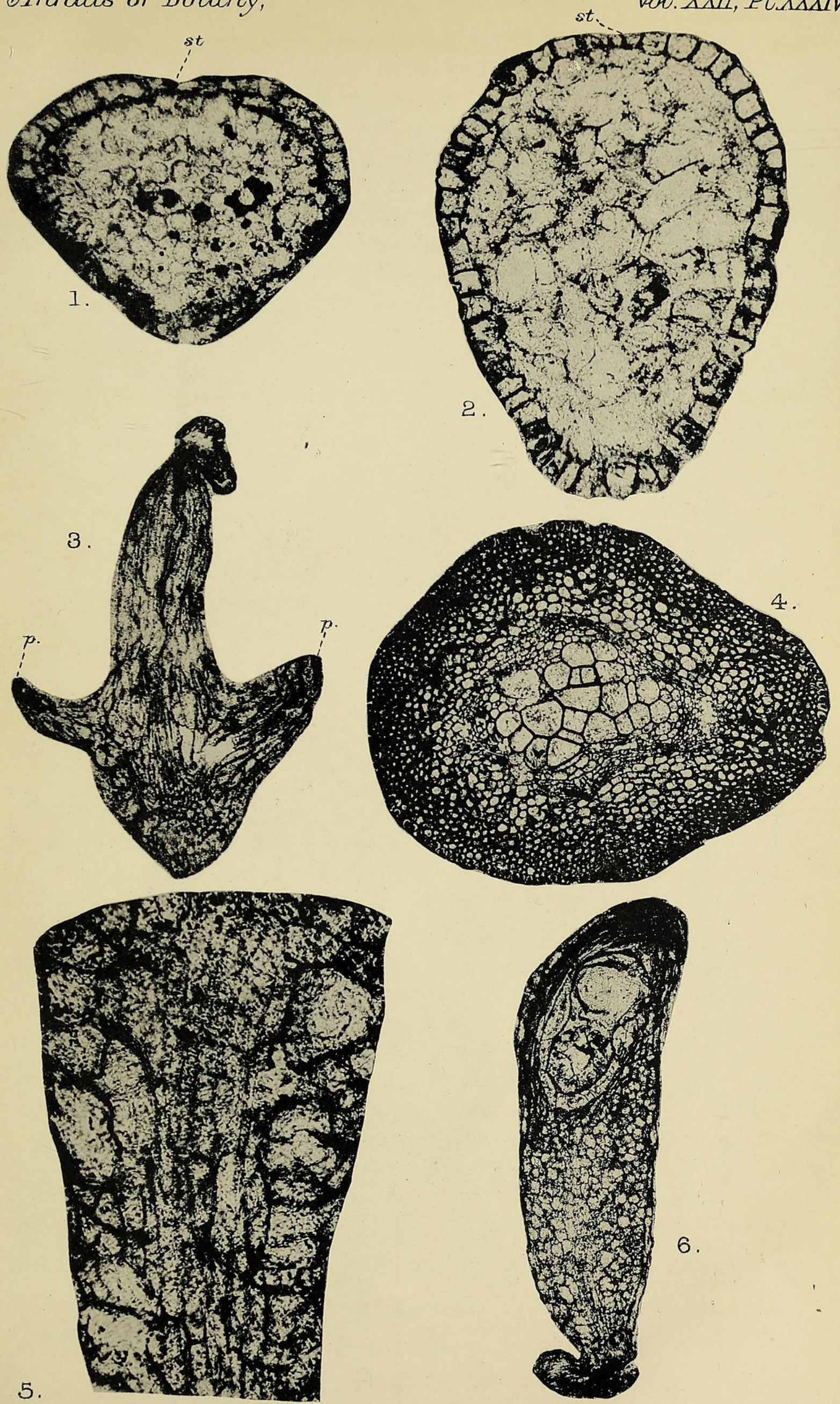

Huth, coll.London

R. SCOTT - BENSONITES AND STARUOPTERIS. 


\section{$2 \mathrm{BHL}$ Biodiversity Heritage Library}

Scott, Rina. 1908. "On Bensonites fusiformis, sp. nov., a fossil associated with Stauropteris burntislandica, P. Bertrand, and on the sporangia of the latter." Annals of botany 22, 683-687. https://doi.org/10.1093/oxfordjournals.aob.a089194.

View This Item Online: https://www.biodiversitylibrary.org/item/232525

DOI: https://doi.org/10.1093/oxfordjournals.aob.a089194

Permalink: https://www.biodiversitylibrary.org/partpdf/318930

\section{Holding Institution}

Smithsonian Libraries

\section{Sponsored by}

Biodiversity Heritage Library

\section{Copyright \& Reuse}

Copyright Status: Not in copyright. The BHL knows of no copyright restrictions on this item.

This document was created from content at the Biodiversity Heritage Library, the world's largest open access digital library for biodiversity literature and archives. Visit BHL at https://www.biodiversitylibrary.org. 